\title{
Bebés / Babies
}

https://doi.org/10.21814/uminho.ed.36.6

\section{Angela Scalabrin Coutinho}

Universidade Federal do Paraná, Brasil 



\section{Bebés}

Quem são os bebés na Sociologia da Infância? Para responder a esta questão é necessário recompor o itinerário epistemológico em torno dos bebés que, num passado muito recente, foram alçados ao estatuto de objeto sociológico. Segundo Gérard Neyrand (2000), no seu estudo emblemático sobre a evolução dos saberes sobre a pequena infância, a conceção de bebé permaneceu grande parte da história no domínio dos campos científicos da medicina, da puericultura e da psicologia. É a partir do final dos anos 1960 e início dos 70, que se observa uma mudança significativa nesse quadro, com o movimento das ideias e dos comportamentos sociais, como a luta pela igualdade de género, a visibilidade homossexual, e em curto tempo depois, a emergência da reprodução assistida.

Estes fenómenos evocam posicionamentos de outras áreas de conhecimento avançando para o que denominamos de um campo interdisciplinar, embora por vezes se caracterize como "multidisciplinar". Importa ressaltar que o bebé se desloca do lugar de objeto exclusivo de estudo de algumas áreas, situadas na sua maioria no campo dos saberes periciais da saúde e da psicologia - quem não conhece a célebre frase de Bernard Martino nos anos 1980 "o bebé é uma pessoa" -, para figurar como problemática de campos até então pouco implicados, como o sociológico.

Nesse quadro, o olhar para os bebés ainda se situava a partir de subáreas da sociologia, como a Sociologia da Família, enquanto os temas relacionados à maternidade e à paternidade como relações sociais eram uma preocupação mais central. Os bebés adquirem visibilidade como atores sociais, dignos de serem estudados por direito próprio, apenas no início do século XXI; portanto, estamos perante um fenómeno muito contemporâneo. Este dado permite formular uma crítica no interior da área da Sociologia da Infância, que ao conclamar, a partir de consistente produção a partir dos anos 1990, a necessidade de rutura com paradigmas psicológicos e sociológicos que situavam as crianças como objetos passivos nos processos de socialização e a infância como fenómeno universal, e a defesa da centralidade do reconhecimento da criança como ator social competente, que tem pontos de vistas que precisam ser considerados, acabou por privilegiar a escuta das 
crianças que utilizam formas de comunicação mais próximas às dos adultos e inviabilizar os bebés.

A marginalização inicial dos bebés na área da Sociologia da Infância tem raízes na visão do bebé como sujeito social com pouco domínio do mundo e das condições que o produzem - e não obstante as reivindicações teóricas da sua competência. Isto é reforçado pela inabilidade metodológica dos/as pesquisadores/as para ouvir os bebés e interpretar o que comunicam.

Nesse sentido, reconhecer os bebés como crianças e que este momento da vida, que inaugura a chegada no mundo, tem relevância em si como acontecimento social e não apenas como idade cronológica a ser vencida para que seja, em momento oportuno, considerado um ator social, que fala, anda e controla os seus esfíncteres, é uma ideia em curso, mas ainda a ser consolidada na área. Coutinho (2010), em estudos desenvolvidos com bebés incluindo uma etnografia visual, demonstra, em diálogo com a teoria weberiana, que os bebés são atores sociais competentes. Eles selecionam e estruturam as suas relações seguindo critérios definidos por eles próprios, a partir da reciprocidade das relações sociais, ou seja, os sujeitos agem mobilizados pelo outro, e das categorias estruturais que incidem nas posições que os agentes ocupam na sociedade, a partir do seu pertencimento de classe, étnico-racial, de género e cultura.

Nesta perspetiva, a Sociologia da Infância apresenta uma grande contribuição para a superação da invisibilidade social do bebé, mas ela ainda esbarra nalguns desafios. Um deles relaciona-se com o facto de que, ainda que tenhamos avançado na compreensão da importância da consideração do ponto de vista do bebé, continuamos a privilegiar determinados grupos sociais, principalmente aqueles que se situam no que sintetiza a normativa social: sociedades ocidentais, industrializadas e bebés institucionalizados. Neste ponto, o alerta de Alma Gottlieb (2000) é incontornável, sendo necessário conhecer os bebés fora do mundo ocidental industrializado para que se possam considerar outros referentes culturais que conformam diferentes modos de ser bebé do que os conhecidos no Ocidente.

Outro desafio relaciona-se com o "como" conhecer os bebés, pois se é certo que os métodos e os procedimentos para a escuta das crianças não podem ser meras adaptações dos utilizados com os adultos, quando as crianças são sujeitos que há pouco tempo habitam o mundo, as escolhas metodológicas são ainda mais exigentes. Isto deve-se ao facto de os bebés utilizarem formas de comunicação como o corpo, o gesto, o olhar, que exigem 
uma observação sistemática e apoiada em recursos que permitam captar o que é ilegível numa observação superficial. Os recursos devem privilegiar a captação das relações em movimento, sendo a fotografia e, em especial, o vídeo, recursos potentes.

A Sociologia da Infância conduz-nos, ainda, à reflexão sobre o compromisso ético nos estudos com bebés, apontando a necessidade de ativar outras formas de identificação do assentimento no desenvolvimento da pesquisa, o que requer do/a pesquisador/a uma atitude vigilante sobre o quê e como os bebés comunicam em relação à sua participação na investigação, que pode ser manifesta de múltiplas formas, e ora apontar para a sua disponibilidade ora para a recusa quanto à participação.

Se a presença dos bebés na Sociologia da Infância é uma conquista recente, sustentada pelos estudos que endossam a legitimidade da sua escuta, o adensamento da sua presença não pode prescindir de uma posição comprometida com o desocultamento das diferentes infâncias dos bebés, a partir do profundo respeito aos seus modos de ser, estar e comunicar no mundo.

\section{Babies}

Who are the babies in the Sociology of Childhood? In order to answer this question, we need to retrace the epistemological itinerary that has been put together around them, as only very recently have babies been raised to the status of sociological object. According to Gérard Neyrand (2000) in his emblematic study of the evolution of knowledge on early childhood, conceptions of the baby remained largely within the realm of scientific fields of medicine, childcare and psychology. It was only in the late 1960s and early 1970 s that there was a significant change in this situation, as ideas and social behavior were shaken up, through struggles for gender equality, homossexual visibility and, shortly thereafter, the emergence of assisted reproduction.

These phenomena were a fundamental stimulus to the involvement of other areas of knowledge, leading to the building of what we refer to as an interdisciplinary field, though sometimes referred to as "multidisciplinary". It is important to emphasize that babies were thus removed from their status as exclusive object of study within a limited number of scientific disciplines, most of them situated within the areas of expert knowledge on health and psychology - who has not heard of Bernard Martino's famous phrase from the 1980 s declaring "the baby is a person" - to take their place 
within problem areas and fields in which they had been previously ignored, such as Sociology.

Within this context, the thinking on babies was still situated within sub-areas of Sociology such as Sociology of the Family, while the related themes of motherhood and fatherhood as social relations were a more central concern. Babies have acquired visibility as social actors, worthy of study in their own right, only within the last ten years; hence, we are dealing with a very contemporary phenomenon. This in turn leads us to point to a conflict within the field of Sociology of Childhood, which through the consistent scientific production of the 1990s, called for the need to break with psychological and sociological paradigms that viewed children as the passive objects of socialization processes and childhood as a universal phenomenon. In scholars' defense of the recognition of children as competent social actors with points of view, preference was given to listening to children who were able to use forms of communication closer to that of adults, relegating babies to a lesser position.

Babies' initial marginalization from the Sociology of Childhood has its roots in a perspective that saw them as social subjects with little mastery over the world and the conditions that produce them, notwithstanding theoretical claims that their competence is recognised. This is further emphasised by the methodological limitations that researchers encounter in listening to babies and interpreting what it is they communicate.

In this sense, the recognition of babies as children and the stage of life which inaugurates one's arrival in the world as a relevant social occurrence in and of itself - and not a mere stage to move beyond- is an accepted but not yet consolidated idea within the field. It means that babies must be considered as social actors, and as ones who speak, walk and control their sphincters. Coutinho (2010), in studies carried out with babies that include visual ethnography, has demonstrated, in dialogue with Weberian theory, that babies are competent social actors. They select and structure their relations according to criteria that they themselves define, through the reciprocity of social relations, that is, as subjects who are mobilized by the other, and through structural categories of social position, such as class, racial/ethnic, gender and cultural identity.

From this perspective, the Sociology of Childhood makes a major contribution to returning social visibility to babies, yet still poses a series of unresolved challenges. One of them is related to the fact that, although 
we have advanced in our understanding of the importance of "bringing in the baby's point of view", we continue to favour particular social groups, and particularly those that represent a synthesis of societal norms: Western industrial societies and institutionalized babies. In this regard, Alma Gottlieb's (2000) warning is essential: we must gather knowledge on babies outside of the Western industrialized world so as to integrate other cultural references that represent modes of babyhood that are distinct from their Western counterparts.

Another challenge has to do with "how" to know babies. The methods and procedures for listening to children cannot be mere adaptations of those applied to the study of adults, and when these children are subjects that have only recently come into the world, methodological issues become even more critical. This flows from the fact that babies communicate with the body, gesture and gaze in ways that demand systematic observation, requiring specific resources that enable researchers to capture that which is illegible through commonplace observation. Resources that focus on relations in movement, such as photography and, above all,video, become powerful tools.

The Sociology of Childhood also leads us to reflections on our ethical commitments to the study of babies, pointing to the need to activate new forms of assent in the development of research. It demands that the researcher maintain a vigilant attitude regarding what and how babies communicate regarding their participation in research, and sensitivity to the many different ways in which they express willingness or unwillingness to take part.

The presence of babies within the Sociology of Childhood is a recent achievement, sustained by studies that demonstrate the legitimacy of listening to them. Providing greater density to this presence implies a commitment to uncovering the "different infancies" of babies, through deep respect for their ways of being and communicating in the world.

\section{Referências / References}

Coutinho, A. M. S. (2010). A ação social dos bebés: um estudo etnográfico no contexto da creche. [Tese de Doutoramento não publicada]. Instituto de Educação da Universidade do Minho, Braga.

Gottlieb, A. (2000). Where have all the babies gone? Towards an Anthropology of infants (and their caretakers). Anthropological Quarterly, 73 (3), 121-132.

Neyrand, G. (2000). L'enfant, la mère et la question du père. Un bilan critique de l'évolution des savoirs sur la petite enfance. Paris: PUF. 